Research Article

\title{
Mathematical Modelling of Alkaline and Ionic Liquid Pretreated Coconut Husk Enzymatic Hydrolysis
}

\author{
Akbarningrum Fatmawati ${ }^{1}$, Ari Anggoroํㅜ, Kamil Adila Muslim¹, Arief Widjaja ${ }^{1 *}$, \\ Tantular Nurtono ${ }^{1}$, Hanny Frans Sangian ${ }^{2}$
}

\author{
${ }^{1}$ Chemical Engineering Department, Institut Teknologi Sepuluh Nopember, Kampus ITS Sukolilo, \\ Surabaya 6011, Indonesia.
}

2Department of Physics, Universitas Sam Ratulangi, Jl. Kampus UNSRAT, Manado, 95115, Indonesia.

Received: 8th February 2021; Revised: 27th April 2021; Accepted: $28^{\text {th }}$ April 2021

Available online: $2^{\text {nd }}$ May 2021; Published regularly: June 2021

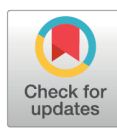

\begin{abstract}
The problem of crude oil reserve shortage and air quality decline currently have led researches on renewable fuel such as bioethanol and biohydrogen. The attempt to provide such biofuel involves the utilization of enormously available wasted materials, lignocellulose. Coconut husk is one of such materials available in Indonesia. The previous work had reported the quantity of total reducing sugar produced after the enzymatic hydrolysis of pretreated coconut husk. The pretreatment methods used were dilute sodium hydroxide solution ( 1 and $4 \% \mathrm{w} / \mathrm{v})$, 1,3methylmethylimidazolium dimethyl phosphate ionic liquid and the combination of both methods. This work focused on constructing the mathematical model which describes the kinetic of those enzymatic hydrolysis reactions. Mathematical model expressions help describing as well as predicting the process behavior, which is commonly needed in the process design and control. The development of mathematical model in this work was done based on the total reducing sugar concentration resulted in batch hydrolysis reaction. The kinetic parameters including initial available substrate $\left(S_{0}\right)$, maximum reaction rate $\left(r_{\max }\right)$, and half-maximum rate constant $\left(K_{M}\right)$. According to the values of half-maximum rate constant $\left(K_{M}\right)$, the enzymatic hydrolysis performance of coconut husk treated using ionic liquid is better than that treated using dilute alkaline solution as the former had shown lower $K_{M}$ value and hence higher enzyme affinity to the substrate. The best hydrolysis result was performed using combination of $1 \%$ dilute sodium hydroxide solution and ionic liquid with kinetic model parameter of $0.5524 \mathrm{~g} / \mathrm{L} . \mathrm{h}$ of $r_{\max }, 0.0409 \mathrm{~g} / \mathrm{L}$ of $K_{M}$, and $4.1919 \mathrm{~g} / \mathrm{L}$ of $S_{0}$.
\end{abstract}

Copyright (C) 2021 by Authors, Published by BCREC Group. This is an open access article under the CC BY-SA License (https://creativecommons.org/licenses/by-sa/4.0).

Keywords: Reducing Sugar; Enzyme; Kinetic; Reaction; Lignocellulose

How to Cite: A. Fatmawati, A. Anggoro, K.A. Muslim, A. Widjaja, T. Nurtono, H.F. Sangian (2021). Mathematical Modelling of Alkaline and Ionic Liquid Pretreated Coconut Husk Enzymatic Hydrolysis. Bulletin of Chemical Reaction Engineering \& Catalysis, 16(2), 331-341 (doi:10.9767/bcrec.16.2.10306.331-341)

Permalink/DOI: https://doi.org/10.9767/bcrec.16.2.10306.331-341

\section{Introduction}

Currently, the world is concerned with energy security and climate change connected with the use of fossil oil as the main source of energy and chemicals [1,2]. Declining air quality caused

\footnotetext{
* Corresponding Author.

Email: arief_w@chem-eng.its.ac.id (A. Widjaja);

Telp: +62-31-5946240, Fax: +62-31-5999282
}

by emission from fossil-based fuel combustion has been detected for decades. The use of biofuel is important strategy to answer problem of energy security and environmental quality [3]. Bioethanol is known as environmentally friendly biofuel as ethanol blend gasoline produce lower $\mathrm{CO}_{2}$ and particulate emission [4,5].

Biorefinery concept has been developed to produce sustainable fuels and chemicals. Biofu- 
els, such as: bioethanol, biodiesel, biohydrogen and biomethane, can be produced from renewable raw materials which are basically naturally available polymers, i.e. starch, cellulose and vegetable oils. Some bio-based products, such as: organic acids, sugar alcohols, furans, and alcohols, had been listed as chemicals that can be potentially produced in biorefinery industries. In order to avoid conflict with food security issue, second generation biofuel is developed where natural non-edible materials are used. In this case, lignocellulose is currently potential source of second-generation biofuel [6].

Lignocellulosic materials are those mainly composed of useful natural large polymer molecules, i.e. cellulose (35-50\%), hemicellulose (20$35 \%$ ), and lignin (5-30\%) [7]. It has natural function as the structural material of plant cell wall and therefore it is characteristically strong and not readily decomposed by microbial activities. This property is especially caused by the present of lignin. There are many kinds of nonedible lignocellulosic material including wood, leaves, straw and husk which are commonly parts of crop, and food processing wastes. Instead of leaving these materials into slow decomposition or combustion, utilizing them in biorefinery will bring benefit both economically and environmentally. Coconut husk (Cocos nucifera) is one of very interesting and abundant lignocellulosic wastes because Indonesia produces a very large amount annually, such as $18.9 \times 10^{6}$ tons in 2017 [8].

Cellulose is the core and most desirable component of lignocellulosic material. Chemically, it is a large homopolymer consisting of $\beta$ $D$-glucose monomer joined by a (1-4)- $\beta$ glycosidic bond. It is the glucose monomer that is the most desirable unit for biofuel production through fermentation process. The cellulose strands are packed into fibrils and there are intermolecular and intramolecular hydrogen bond as well as van der Waals interaction within the fibrils causing the polymer to be crystalline and water soluble. A very high degree of polymerization $(10,000$ or more glucose unit per strand) also supports these properties. However, not all parts of the fibrils are crystalline. The internal parts are more amorph. Hemicellulose is a heteropolymer of five and six carbon sugar units which binds to the cellulose fibrils surface as the matrix material encasing the fibril. The $\mathrm{C} 6$ sugars are usually glucose, mannose, and galactose, while the C5 sugars are xylose and arabinose. The degree of polymerization of hemicellulose is lower than cellulose. Lignin is a large natural aromatic polymer which binds with hemicellulose. The structure of lignin involves three monomers which are coniferyl, sinapyl and p-coumaryl alcohols. In the large molecule, these monomers compose guaiacyl, syringil, and p-hydroxyphenyl subunits $[9,10]$.

The presence of lignin at the outmost part of the lignocellulose material and the crystallinity of the cellulose have caused the structure is recalcitrant [11]. Meanwhile, in order to produce fuel or several other chemicals, the cellulose and hemicellulose must be converted into $\mathrm{C} 6$, and C5 sugar through enzymatic hydrolysis. Therefore, the basic steps lignocellulose conversion into biofuel are pretreatment or delignification, enzymatic hydrolysis, and fermentation. It has been reported that the pretreatment step is not only expected to remove lignin but also increase the accessibility of hydrolytic enzyme and minimize the formation of further degradation products formed from sugar and lignin subunit.

The enzymatic hydrolysis of lignocellulosic materials involves the synergic work of cellulase enzyme system, whilst the enzyme mixture, involving cellulase, cellobiase, and xylanase, are also used to improve sugar production yield. Cellulase enzyme system, which catalyze cellulose hydrolysis into glucose consists of three enzymes, i.e. endoglucanases (EG, EC 3.2.1.4), cellobiohydrolases or exoglucanases $(\mathrm{CBH}, \mathrm{EC}$ 3.2.1.91), and $\beta$-glucosidases (BG, EC 3.2.1.21). Endo- $\beta$-1,4-xylanase (EC 3.2.1.8) is an enzyme that is usually added to hydrolyze xylan hemicellulose in order to improve the action of cellulase on cellulose component [5]. A reaction kinetic equation to describe and predict the enzymatic hydrolysis reaction behavior widely employed in process design and research had long been derived by Henri (1902) and Michaelis-Menten (1913) [12]. The equation related the rate of hydrolysis reaction to substrate concentration as follows:

$$
r=\frac{r_{\max } S}{K_{M}+S}
$$

where $r$ is hydrolysis reaction rate (g/L.h), $r_{\max }$ is maximum hydrolysis rate (g/L.h), $K_{M}$ is the substrate concentration when the rate is equal to half of $r_{\max }(\mathrm{g} / \mathrm{L}), S$ is substrate concentration $(\mathrm{g} / \mathrm{L})$, and $t$ is reaction time $(\mathrm{h})$.

According to the reaction rate Equation (1) above, the rate of reaction depends on the substrate concentration at small substrate concentration but no longer does at high substrate concentration. The kinetic coefficient $\left(r_{\max }\right)$ and constant $\left(K_{M}\right)$ are usually determined by fitting the relationship between initial rate of product concentration change and experimentally var- 
ied initial substrate concentrations. Several different forms of equation were proposed for describing the enzymatic hydrolysis reaction of pretreated lignocellulose materials. The equations are presented in Table 1.

Many pretreatment methods can be employed to achieve the pretreatment goal, including, physical, chemical, physio-chemical and biological methods $[13,14]$. Mechanical pretreatment, such as: chipping, grinding and milling to achieve fine particle size $(0.2-10 \mathrm{~mm})$ can reduce degree of polymerization and increase specific surface and therefore increase the access of enzyme onto the material $[15,16]$. In spite of those size reduction pretreatment, extrusion, ultrasound and microwave are novel physical pretreatment. Ultrasound and microwave pretreatment are usually combined with chemical such as acid and alkali. Chemical pretreatment using alkali and acid have long been used to treat lignocellulose. Dilute $\mathrm{H}_{2} \mathrm{SO}_{4}$ solution is usually performed at high temperature $(>120$ $\left.{ }^{\circ} \mathrm{C}\right)$ to solubilize hemicellulose so that cellulose is more accessible to hydrolytic enzyme. Various dilute alkali of sodium, potassium, calcium and ammonium hydroxides are used for lignocellulose pretreatment which affects lignin solubilization and therefore increase cellulose digestibility [14]. Sodium hydroxide is cheaper than potassium hydroxide and has higher solubility than $\mathrm{Ca}(\mathrm{OH})_{2}$. This alkaline pretreatment can be performed at low temperature [17]. Wang et al. [18] used dilute sodium hydroxide to treat sugarcane bagasse for ethanol production and found the optimum condition of solid-liquid ratio $1: 9.1$, and $3 \% \mathrm{NaOH}$ concentration, at $50{ }^{\circ} \mathrm{C}$ and $4 \mathrm{~h}$ reaction time. Ionic liquids (ILs) are new interesting method for pretreatment of lignocellulose [19]. Ionic liquids are salts which present as liquid at room temperature and composed of large organic cation and small inorganic anion. Ionic liquids have advantageous properties such as chemical and thermal stability, non-flammability, and low vapor pressure $[13,20]$. Combined pretreatment of $0.2 \mathrm{M}$ sulfuric acid at $121^{\circ} \mathrm{C}, 2 \mathrm{~h}$ and ionic liquid 1-ethyl-3-methylimidazolium acetate at $130^{\circ} \mathrm{C}, 3 \mathrm{~h}$, was used to treat bamboo. This resulted in $80 \%$ glucose yield after enzymatic hydrolysis [21]. The use of combined pretreatment of $1 \% \mathrm{NaOH}$ at $80{ }^{\circ} \mathrm{C}, 16 \mathrm{~h}$ and 1,3 methylmethylimida-zolium dimethyl phosphate at $120^{\circ} \mathrm{C}, 15 \mathrm{~h}$ had been used to treat coconut husk and resulted in $0.13 \mathrm{~g}$ sugar/g dried lignocellulose [22]. The use of combined pretreatment using sodium hydroxide and recycled 1,3methylmethyl-imidazolium dimethyl phosphate had also been done and showed similar to combined treatment with fresh ionic liquid [23].

This work focuses on the building of mathematical model for enzymatic hydrolysis of coconut husk which had been treated with sodium hydroxide, ionic liquid of 1,3 methylmethylimidazolium dimethyl phosphate and the combination of both pretreatments. The result of enzymatic hydrolysis had been performed by previous study [22]. However, the mathematical model for the enzymatic hydrolysis reaction kinetic has not been reported. This mathematical model is very important for predicting the process behavior, which is commonly needed in the process design and control. A Michaelis-Menten based kinetic equation involving additional unknown initial substrate concentration accessible for enzyme is newly proposed to be applied for coconut coir in this paper. An iterative computation procedure with the aid of powerful software was performed to obtain the kinetic equation coefficient and constant.

\section{Materials and Methods}

\subsection{Materials}

Coconut husk was obtained from coconut meat processing industry in South Minahasa, North Sulawesi, Indonesia. The husk was sundried, milled, and screened to obtain 120 mesh coconut coir powder. The pretreatment chemicals were sodium hydroxide $(\geq 99 \%$, Merck, Germany). Trimethyl phosphate $(\geq 99.5 \%$, Sigma Aldrich, USA) and 1-methylimidazole ( $\geq$ 99\%, Sigma Aldrich, USA) were used to synthesize 1,3-dimethylimidazolium dimethyl phosphate ionic liquid. Citric acid monohydrate (99.5 - 100.5\%, Merck, Germany) and trisodium citrate dihydrate (99-101.0\%, Merck, Germany) were used to make citrate buffer solution. The enzymes used were cellulase from A. niger $(\geq$ 0.3 units/mg solid, Sigma Aldrich, Japan) and xylanase from $T$. longibrachiatum $(\geq 1.0$ units/mg solid Sigma Aldrich, Mexico). 3,5Dinitrosalicylic acid ( $\geq 98 \%$, Sigma Aldrich, USA), sodium metabisulfite ( $\geq 99 \%$, Sigma Aldrich, USA), sodium hydroxide ( $\geq 99 \%$, Merck, Germany) and potassium sodium tartrate tetrahydrate (99-102\%, Merck, Germany) were used for reducing sugar analysis.

\subsection{Coconut Husk Pretreatment}

In this work, enzymatic hydrolysis kinetic model constants are determined for coconut coir, unpretreated, and pretreated using 4 different chemical methods, which are pretreat- 
Table 1. Kinetic models of previously proposed lignocellulose enzymatic hydrolysis.

\begin{tabular}{|c|c|c|c|}
\hline Substrate & Enzyme & Equation & Ref \\
\hline \multirow{3}{*}{$\begin{array}{l}\text { Hot water } \\
\text { and dilute } \\
\text { sulfuric acid } \\
\text { pretreated } \\
\text { kitchen waste }\end{array}$} & \multirow{3}{*}{$\begin{array}{l}\text { Cellulase, } \\
\text { amylogluco- } \\
\text { sidase, } \beta- \\
\text { glucosidase }\end{array}$} & First order dynamic equation & \multirow[t]{3}{*}[30]{} \\
\hline & & $C=C_{m}\left(1-e^{-k t}\right)$ & \\
\hline & & $\begin{array}{l}C=\text { the change in glucose concentration with respect to initial } \\
\text { glucoses concentration }\left(i . e ., \mathrm{C}(\mathrm{t})-\mathrm{C}_{0}\right)(\mathrm{g} / \mathrm{L}) ; C_{m}=\text { maximum glu- } \\
\text { cose accumulated at infinite hydrolysis time, }(\mathrm{g} / \mathrm{L}) ; k=\text { rate con- } \\
\text { stant of glucose production, }(1 / \mathrm{h}) .\end{array}$ & \\
\hline
\end{tabular}

\begin{tabular}{|c|c|c|c|}
\hline $\begin{array}{l}\text { Steam- } \\
\text { exploded rice } \\
\text { straw }\end{array}$ & $\begin{array}{l}\text { Celluase } \\
\text { from Tricho- } \\
\text { derma viri- } \\
\text { dae }\end{array}$ & $\begin{array}{l}\text { Michaelis-Menten like equation: } \\
v_{0}=\frac{V_{\text {emax }} E_{0}}{K_{e}+E_{0}} \\
v_{0}=\text { initial hydrolysis rate, }(\mathrm{g} / \mathrm{L} . \mathrm{min}) ; E_{0}=\text { initial enzyme con- } \\
\text { centration, }(\mathrm{g} / \mathrm{L}) ; V_{e m a x}=\text { maximum velocity, }(\mathrm{g} / \mathrm{L} . m i n) ; K_{e}=\text { cor- } \\
\text { responding half saturation constant, }(\mathrm{g} / \mathrm{L}) \text {. }\end{array}$ & {$[32]$} \\
\hline $\begin{array}{l}\text { Microcrystal- } \\
\text { line cellulose } \\
\text { and pretreat- } \\
\text { ed wheat } \\
\text { straw }\end{array}$ & $\begin{array}{l}\text { ENZ-SC01 } \\
\text { cellulase } \\
\text { mixture } \\
\text { Novozyme } \\
188\end{array}$ & $\begin{array}{l}\text { Empirical reducing-sugar concentration-time formula to deter- } \\
\text { mine maximum reaction rate: } \\
\qquad \begin{array}{l}y=\frac{a x}{b+x}+\frac{c x}{d+x} \\
X=\text { time, }(\mathrm{h}) ; y=\text { reducing sugar concentration, }(\mathrm{g} / \mathrm{L} 0 ; a, c= \\
\text { empirical coefficients, }(\mathrm{g} / \mathrm{L}) ; b, d=\text { empirical constants, }(\mathrm{h}) \text {. }\end{array}\end{array}$ & [31] \\
\hline Waste papers & $\begin{array}{l}\text { Celluclast } \\
1.5 \mathrm{~L}- \\
\text { Novozyme } \\
188 \text { mixture } \\
\text { Cellic Ctec } 1\end{array}$ & $\begin{array}{l}\text { Initial reaction rate equation: } \\
V=\frac{1}{1+k_{3} t} \frac{k_{2} S_{0} E_{0}}{K_{e}+E_{0}} \\
V=\text { reaction rate, }(\mathrm{g} / \mathrm{L} \cdot \mathrm{h}) ; S_{0}=\text { initial glucan concentration, } \\
(\mathrm{g} / \mathrm{L}) ; E_{0}=\text { initial enzyme concentration, }(\mathrm{g} / \mathrm{L}) ; k_{2}, k_{3}=\text { rate con- } \\
\text { stants, }\left(\mathrm{h}^{-1}\right) ; t=\text { time, }(\mathrm{h}) ; K_{e}=\text { equilibrium constant, }(\mathrm{g} / \mathrm{L})\end{array}$ & {$[34]$} \\
\hline $\begin{array}{l}\text { Media milled } \\
\text { microcrystal- } \\
\text { line cellulose }\end{array}$ & $\begin{array}{l}\text { Cellulase } \\
\text { from } T \text {. } \\
\text { reesei }\end{array}$ & $\begin{array}{l}\text { Product competitive inhibition model: } \\
v_{0}=\frac{V_{\max }[S]_{0}}{K_{m}\left(1+\frac{[P]}{K_{I}}\right)+[S]_{0}} \\
v_{0}=\text { initial hydrolysis rate, }(\mathrm{g} / \mathrm{L} \cdot \min ) ; V_{\max }=\text { maximum hydroly- } \\
\text { sis rate, }(\mathrm{g} / \mathrm{L} . \mathrm{min}) ;[\mathrm{S}]_{0}=\text { initial substrate concentration, }(\mathrm{g} / \mathrm{L}) ; \\
K_{m}=\text { Michaelis-Menten constant, }(\mathrm{g} / \mathrm{L}) ;[\mathrm{P}]=\text { product concentra- } \\
\text { tion, }(\mathrm{g} / \mathrm{L}) ; K_{I}=\text { inhibition constant. }\end{array}$ & {$[29]$} \\
\hline
\end{tabular}

Dilute sulfu- $\quad$ Celluclast $\quad$ Empirical power equation for reducing sugar concentrationric acid pre- $1.5 \mathrm{~L}-\quad$ time relation to obtain initial reaction rates at several initial treated coco- Novozyme substrate concentrations:

nut coir $\quad 188$ mixture $\quad S=a \cdot t^{b}$

$S=$ substrate sugar concentration, $(\mathrm{g} / \mathrm{L}) ; t=$ time, $(\mathrm{h}) ; a, b=$ empirical coefficient and power

The Michaelis-Menten equation for initial rate and initial substrate concentration relation to obtain kinetic equation coefficient and constant:

$$
r=\frac{V_{m} S_{0}}{K_{M}+S_{0}}
$$

$r=$ initial reaction rate, $(\mathrm{g} / \mathrm{L} . \mathrm{h}) ; V_{m}=$ maximum rate, $(\mathrm{g} / \mathrm{L} . \mathrm{h}) ; S_{0}$ = initial substrate concentration; $K_{M}=$ half saturation constant, $(\mathrm{g} / \mathrm{L})$ 
ment using dilute sodium hydroxide solution with concentration of $1 \%$, and $4 \%(\mathrm{w} / \mathrm{v})$, ionic liquid, and sequential combination of $1 \% \mathrm{NaOH}$ solution and ionic liquid. The ionic liquid used was 1,3-dimethylimidazolium dimethyl phosphate or [mmim] [dmp]. Dilute sodium hydroxide pretreatment was performed at $80{ }^{\circ} \mathrm{C}$ and 16 hours with 6 grams solid in $250 \mathrm{~mL}$ solution. The ionic liquid preparation and the pretreatment method using the ionic liquid was the same as that described in the previous articles [22].

\subsection{Enzymatic Hydrolysis}

For each of the different chemically pretreated, and unpretreated coconut coir, the enzymatic hydrolysis was carried out using two enzymes, which are cellulase and xylanase. One gram of the pretreated coconut coir was suspended in $30 \mathrm{~mL} 0.1 \mathrm{M}$ citrate buffer solution of $\mathrm{pH}$ 3.0, in an Erlenmeyer flask. Each of the enzymes was added with a dose of $18.6 \mathrm{U} / \mathrm{g}$ substrate. The flask was submerged in an oil bath maintained at $60{ }^{\circ} \mathrm{C}$ which was mounted on a hot plate magnetic stirrer. The suspension inside the flask was kept slowly stirred for 48 h. Samples were taken every two hours from time zero until $12 \mathrm{~h}$, and afterwards, every $6 \mathrm{~h}$ until $48 \mathrm{~h}$. The amount of each of the samples was $0.4 \mathrm{~mL}$, which was placed in a $1.5 \mathrm{~mL} \mathrm{mi-}$ crocentrifuge tube. The enzyme inactivation was done by put the tube in a boiling water for 10 minutes. Afterwards, the sample were centrifuged (Hermle Labortechnik GmbH-Z236K) at $10,000 \mathrm{rpm}$ and $4{ }^{\circ} \mathrm{C}$ for 10 minutes. As much as $0.2 \mathrm{~mL}$ supernatant was taken and diluted using $1.8 \mathrm{~mL}$ deionized water, put into a $15 \mathrm{~mL}$ test tube, and added with $3.0 \mathrm{~mL}$ dinitrosalicylic (DNS) solution reagent. The mixture was then boiled for 10 minutes and cooled immersing cold water for 10 minutes. The absorbance of the final solution was measured using spectrophotometer (Cecil 1100, UK) at 540 $\mathrm{nm}$ to obtain reducing sugar concentration. The DNS solution reagent was formulated according to the method by Miller [24].

\subsection{Mathematical Modeling and Kinetic Con- stants Determination}

Cellulose hydrolysis product concentration was experimentally determined as total reducing sugar concentration. In this work, we modeled glucose molecule as the hydrolysis reaction product and cellulose molecule as the substrate. By involving stoichiometric relation in the hydrolysis reaction, the substrate concen- tration can be connected to product concentration as follows:

$$
S=\left(S_{0}-\frac{P}{1.1}\right)
$$

The constant 1.1 in Equation (2) emerges from the molecular weight ratio of glucose (180 $\mathrm{g} / \mathrm{mol})$ to glucan $(162 \mathrm{~g} / \mathrm{mol})$. Therefore, the Michaelis-Menten Equation shown in Equation (1) can be adopted and expanded to obtain the following reaction rate equation:

$$
r=\frac{d P}{d t}=\frac{r_{\max }\left(S_{0}-\frac{P}{1.1}\right)}{K_{M}+\left(S-\frac{P}{1.1}\right)}
$$

where $S$ is substrate concentration $(\mathrm{g} / \mathrm{L}), S_{0}$ is initial concentration of substrate accessible to the enzymes after pretreatment process $(\mathrm{g} / \mathrm{L})$, and $P$ is hydrolysis product concentration, (g/L)

According to Equation (3), there will be one coefficient $\left(r_{\max }\right)$ and two constants $\left(K_{M}\right.$, and $\left.S_{0}\right)$ that have to be evaluated. Firstly, from the experiments, data set of reaction times $(t)$ and product or reducing sugar concentrations $\left(P_{\text {exp }}\right)$ were obtained for each of the pretreatment method. Then, initial guess for coefficient and constants $\left(r_{\text {max }}, K_{M}\right.$, and $\left.S_{0}\right)$ were proposed. The values of the calculated reducing sugar concentration $\left(P_{\text {calc }}\right)$ subsequently were obtained by solving the differential equation expressed in Equation (3) numerically. In this work, this was performed using the aid of ODE45 function. The ODE 45 is a MATLAB built-in function that is based on an explicit Runge-Kutta $(4,5)$ or Dorman-Prince pair $[25,26]$. The desired final values of coefficient and constants $\left(r_{\text {max }}, K_{M}\right.$, and $\left.S_{0}\right)$ then were determined iteratively through optimization procedure using MATLAB built-in optimization function, fminsearch. This MATLAB built-in function uses the simplex search method developed by Lagarias et al. [27]. In this work, the following objective function was set to be minimum:

$$
f_{o b j}=\sum_{i=1}^{n}\left(P_{e x p, i}-P_{c a l c, i}\right)^{2}
$$

where $P_{\exp }$ is product (total reducing sugar) concentration obtained experimentally (g/L), $P_{\text {calc }}$ is product (total reducing sugar) concentration obtained through numerical solution of differential equation expressed in Equation (3) $(\mathrm{g} / \mathrm{L}), i$ is summation index $(i=1,2,3, \ldots, n)$, and $n$ is number of experiment data. 


\section{Results and Discussion}

In this work, based on the expansion of the Michaelis-Menten enzymatic hydrolysis kinetic equation, the kinetic model coefficient and constants $\left(r_{\max }, K_{M}\right.$, and $\left.S_{0}\right)$ had been obtained after constructing and running simulation program using MATLAB software. Using the kinetic model coefficient and constants $\left(r_{\max }, K_{M}\right.$, and $S_{0}$ ), the calculated total reducing sugar (product) concentrations from enzymatic hydrolysis reaction using mixture of cellulase and

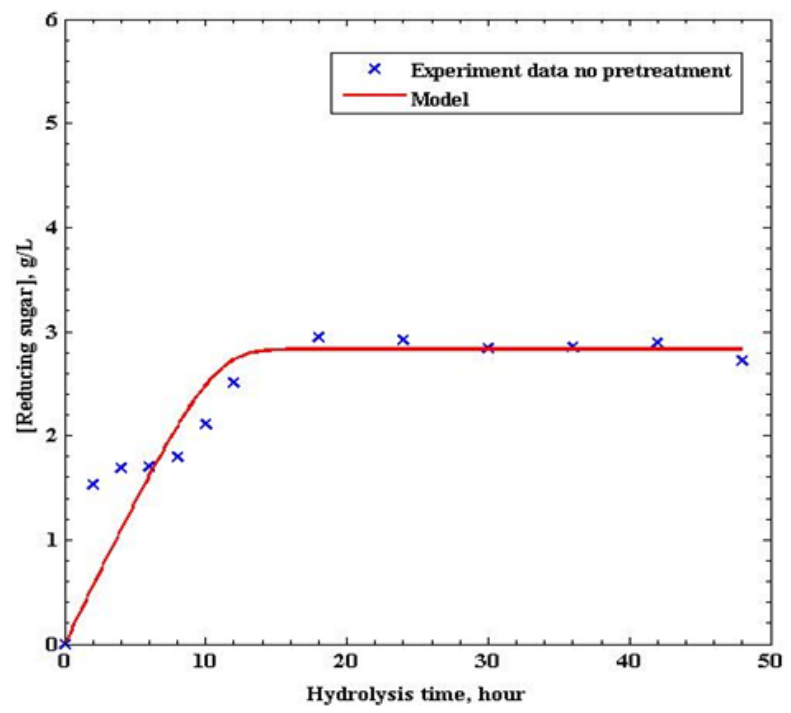

Figure 1. The reducing sugar concentration profile resulted from enzymatic hydrolysis of unpretreated coconut husk with the model coefficient of determination $\left(\mathrm{R}^{2}\right)=0.8159$ and sum square of error $=1.6036$.



xylanase enzyme are depicted in Figure 1-3, along with the experimental values.

Figure 1 shows the result for unpretreated coconut husk enzymatic hydrolysis. The reducing sugar concentration increase with reaction time but starts to decelerate after more than 10 hours of reaction and subsequently reaches constant value at about $3 \mathrm{~g} / \mathrm{L}$ after 18 -h reaction time. The model shows good approximation to the data as the values of $\mathrm{R}^{2}(0.8159)$ and sum of sum square of error (1.6036) are quite satisfying. The hydrolysis results for pretreated coconut husk are depicted on Figure 2-3. According to the values of the $\mathrm{R}^{2}$, the modeling results are quite good for the pretreatment using dilute sodium hydroxide solution and single ionic liquid but not too good for the combined pretreatment of $1 \% \mathrm{NaOH}$ and ionic liquid. However, the model can still keep up with data trend therefore can still be used as prediction of the process. In addition, the value of $\mathrm{R}^{2}$ cannot be depended as the basis of validity for biochemical nonlinear data since $\mathrm{R}^{2}$ is more appropriate when used in evaluating a linear regression [28].

Analyses of variance (ANOVA) were performed with significance level $(\alpha)$ of 0.05 or confidence level of 0.95 to evaluate the significance of the mathematical model for the unpretreated, and each of the pretreated coconut coir. The ANOVA for the coconut coir enzymatic hydrolysis model of this research is summarized in Table 3. The table presents the standard error (SE) or variance of the model, the $F$ value $(F)$ and the significance probability $(p$ -



Figure 2. The reducing sugar concentration profile resulted from enzymatic hydrolysis of coconut husk with (a) $1 \% \mathrm{NaOH}$ pretreatment with the model coefficient of determination $\left(\mathrm{R}^{2}\right)=0.9027$ and sum square of error $=1.44084$, and (b) $4 \% \mathrm{NaOH}$ pretreatment with the model coefficient of determination $\left(\mathrm{R}^{2}\right)=0.8285$ and sum square of error $=2.0529$. 
value) and the $F$-value at significance level 0.05 $\left(F_{\text {critical }}\right)$. From the ANOVA result, it can be seen that the $p$-value obtained is much lower than the significance level ( $p$-value $<0.05)$ and also the $F$-value is much higher than the $F_{\text {criti- }}$ cal. This shows that the model is significant.

The values of kinetic model coefficient and constants resulted from the optimization procedure of this work, for the pretreated and unpretreated coconut husk are presented in Table 2. From the result, it can be seen that the $K_{M}$ values of pretreatment involving ionic liquid are lower than other pretreatment method which may imply that ionic liquid pretreated coconut husk has higher affinity to the enzyme. This is also supported by the fact that the highest value of accessible initial substrate concentration $\left(S_{0}=4.1919\right)$ is for the pretreatment using combination of $1 \% \mathrm{NaOH}$ and ionic liquid although the maximum rate does not exhibit the highest value. This shows that this pretreatment method resulted in the biggest accessible part of cellulose for hydrolytic enzyme which then yielding the highest total reducing sugar
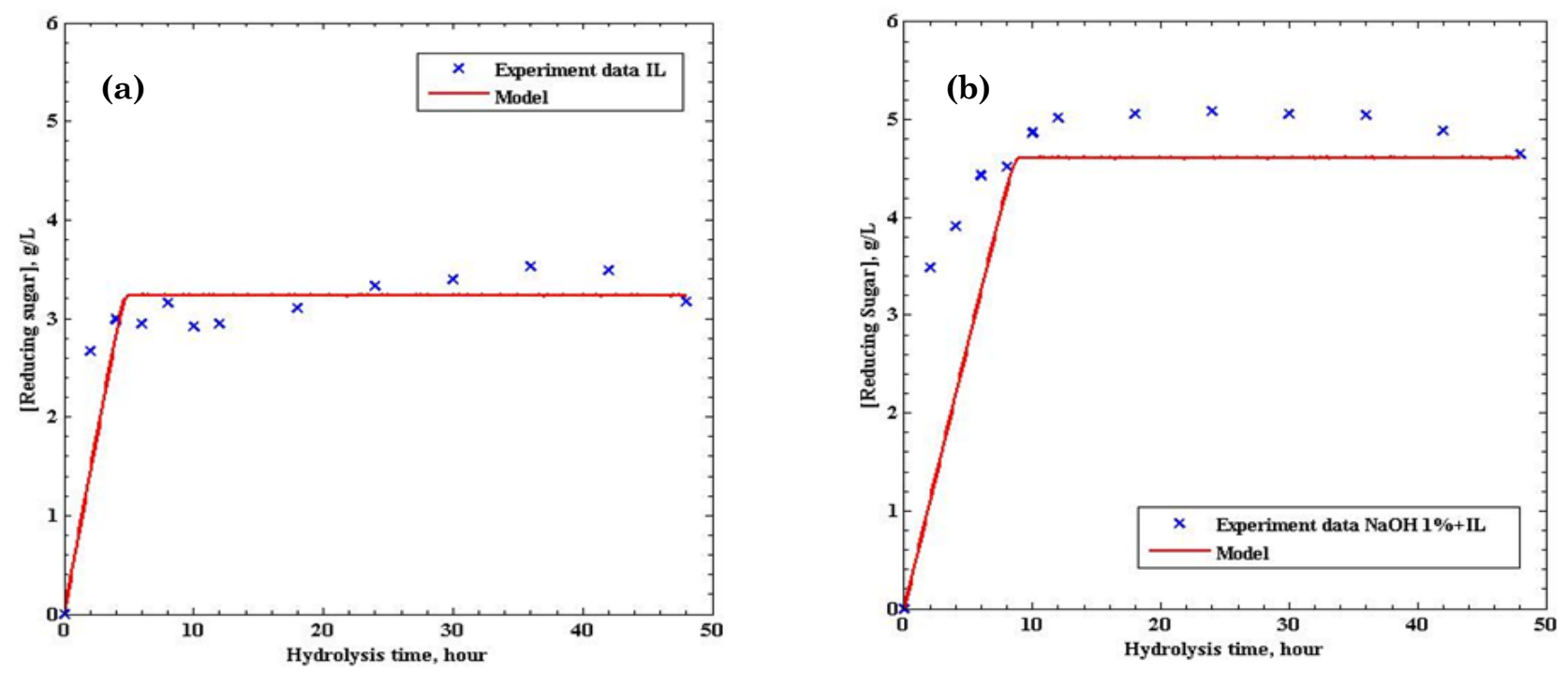

Figure 3. The reducing sugar concentration profile resulted from enzymatic hydrolysis of coconut husk with (a) ionic liquid pretreatment with the model coefficient of determination $\left(R^{2}\right)=0.7899$ and sum square of error $=2.0634$, and (b) $1 \% \mathrm{NaOH}$ and ionic liquid pretreatment with the model coefficient of determination $\left(\mathrm{R}^{2}\right)=0.5112$ and sum square of error $=11.2307$.

Table 2. The results for kinetic model constants of coconut coir enzymatic hydrolysis.

\begin{tabular}{lccc}
\hline Pretreatment Method & $r_{\max },(\mathrm{g} / \mathrm{L} \cdot \mathrm{h})$ & $S_{0},(\mathrm{~g} / \mathrm{L})$ & $K_{M},(\mathrm{~g} / \mathrm{L})$ \\
\hline Unpretreated & 0.3157 & 2.5746 & 0.2920 \\
$1 \% \mathrm{NaOH}$ & 1.9738 & 3.4447 & 0.4193 \\
$4 \% \mathrm{NaOH}$ & 0.8669 & 2.9907 & 0.2155 \\
Ionic Liquid & 0.7268 & 2.9428 & 0.0428 \\
$1 \% \mathrm{NaOH}$ and Ionic Liquid & 0.5524 & 4.1919 & 0.0409 \\
\hline
\end{tabular}

Table 3. The summary of ANOVA of kinetic model for unpretreated and pretreated coconut coir.

\begin{tabular}{lcccc}
\hline Pretreatment & Standard Error (SE) & $F$-value & $p$-value & $F_{\text {critical }}$ \\
\hline No Pretreatment & 0.1458 & 81.0380 & $1.263 \times 10^{-7}$ & \\
$\mathrm{NaOH} \mathrm{1 \%}$ & 0.1310 & 143.026 & $4.326 \times 10^{-9}$ & \\
$\mathrm{NaOH} \mathrm{4 \%}$ & 0.1866 & 84.0309 & $3.211 \times 10^{-10}$ & 4.84434 \\
Ionic Liquid & 0.1876 & 95.0277 & $1.464 \times 10^{-10}$ & \\
$\mathrm{NaOH} \mathrm{1 \%} \mathrm{+} \mathrm{Ionic} \mathrm{Liquid}$ & 1.0210 & 34.5239 & $8.730 \times 10^{-8}$ & \\
\hline
\end{tabular}


concentration as depicted on Figure 3b. The ionic liquid pretreatment can change the structure of cellulose to be more amorph. The structure of cellulose had changed from cellulose I into cellulose II after pretreated with the ionic liquid and therefore it will be easier to be enzymatically hydrolyzed [22]. Pretreatments using dilute alkaline solution ( 1 and $4 \% \mathrm{NaOH}$ ) have given higher maximum rate of reaction than those involving ionic liquid, alone and its combination with dilute alkaline $(1 \% \mathrm{NaOH})$ but they also exhibit high $K_{M}$ values which counteract the high maximum hydrolysis rate values and therefore lower the hydrolysis rate. The unpretreated coconut husk has the lowest value of $r_{\max }$ and $S_{0}$ with high value of $K_{M}$. This shows that pretreatment is needed to increase reaction rate and the accessible part of cellulose fibril. The need of pretreatment to increase reaction rate is also implied by the hydrolysis kinetic of milled microcrystalline cotton cellulose as reported by Yeh et al. [29] (see Table 3) where the value of $V_{\max }$ is higher for $120 \mathrm{~min}$ milled $3 \%$ suspension of cotton cellulose $\left(V_{\max }=\right.$ $0.304 \mathrm{~g} / \mathrm{L} . \mathrm{min})$, compared to the untreated one $\left(V_{\max }=0.076 \mathrm{~g} / \mathrm{L} . \mathrm{min}\right)$. However, this is not the same as kitchen waste, reported by Cekmecelioglu and Uncu [30], where, as seen in Table 4, the $C_{m}$ and $k$ values are higher for the unpretreated waste compared to the pretreated one. This implied that pretreatment lowered the hydrolysis rate and final glucose concentration, and hence pretreatment was not suggested for the kitchen waste hydrolysis [30]. The other kinetic studies summarized in Table 4 did not compare the kinetic parameters of the pretreated and unpretreated substrate.

Table 4 presents the kinetic model parameters from several lignocellulose materials with different pretreatment methods reported in several publications. These parameters determination involved several batches of hydrolysis experiments. Contrarily, the kinetic coefficients and constants in this research were de-

Table 4. Kinetic model and its parameter from several sources.

\begin{tabular}{|c|c|c|c|}
\hline Substrate & Kinetic Model & Parameter values & Ref. \\
\hline $\begin{array}{l}\text { Hot water and di- } \\
\text { lute sulfuric acid } \\
\text { pretreated kitchen } \\
\text { waste }\end{array}$ & $C=C_{m}\left(1-e^{-k t}\right)$ & $\begin{array}{l}\text { No pretreatment: } C_{m}=40.54 \mathrm{~g} / \mathrm{L} ; \\
k=0.644 \mathrm{~h}^{-1} ; \mathrm{R}^{2}=0.989 \\
\text { Hot water: } C_{m}=38.90 \mathrm{~g} / \mathrm{L} ; \\
k=0.406 \mathrm{~h}^{-1} ; \mathrm{R}^{2}=0.962 \\
1 \% \text { Acid: } C_{m}=77.52 \mathrm{~g} / \mathrm{L} ; k=0.128 \mathrm{~h}^{-1} ; \\
\mathrm{R}^{2}=0.958\end{array}$ & {$[30]$} \\
\hline $\begin{array}{l}\text { Steam-exploded } \\
\text { rice straw }\end{array}$ & $v_{0}=\frac{V_{e \max } E_{0}}{K_{e}+E_{0}}$ & $\begin{array}{l}\text { Washed: } V_{e \max }=0.18 \mathrm{~g} / \mathrm{L} \cdot \min ; \\
K_{e}=4.08 \mathrm{~g} / \mathrm{L} ; \mathrm{R}^{2}=\mathrm{NA} . \\
\text { Unwashed: } V_{e \max }=0.16 \mathrm{~g} / \mathrm{L} . \mathrm{min} ; \\
K_{e}=4.24 \mathrm{~g} / \mathrm{L} ; \mathrm{R}^{2}=\mathrm{NA} .\end{array}$ & {$[32]$} \\
\hline $\begin{array}{l}\text { Thermo-acidically } \\
\text { pretreated wheat } \\
\text { straw }\end{array}$ & $\begin{array}{l}\text { Empirical model to obtain } r_{\text {max }} \text { : } \\
y=\frac{a x}{b+x}+\frac{c x}{d+x}\end{array}$ & $r_{\max }=9.6 \mathrm{~g} / \mathrm{L} . \mathrm{h} ; \mathrm{R}^{2}=\mathrm{NA}$. & {$[31]$} \\
\hline Waste papers & $V=\frac{1}{1+k_{3} t} \frac{k_{2} S_{0} E_{0}}{K_{e}+E_{0}}$ & $\begin{array}{l}\text { Newspaper: } k_{2}=0.79 \mathrm{~h}^{-1} ; k_{3}=2.324 \mathrm{~h}^{-1} ; \\
K_{e}=25.30 \mathrm{~g} / \mathrm{L} ; \mathrm{R}^{2}=0.9969 \\
\text { Cardboard: } k_{2}=0.3408 \mathrm{~h}^{-1} ; \\
k_{3}=0.9865 \mathrm{~h}^{-1} ; K_{e}=18.82 \mathrm{~g} / \mathrm{L} ; \\
\mathrm{R}^{2}=0.9923 .\end{array}$ & {$[18]$} \\
\hline $\begin{array}{l}\text { Media milled mi- } \\
\text { crocrystalline cel- } \\
\text { lulose }\end{array}$ & $v_{0}=\frac{V_{\max }[S]_{0}}{K_{m}\left(1+\frac{[P]}{K_{I}}\right)+[S]_{0}}$ & $\begin{array}{l}\text { Unpretreated: } V_{\max }=0.076 \mathrm{~g} / \mathrm{L} . \mathrm{min} \\
K_{m}=9.844 \mathrm{~g} / \mathrm{L} ; K_{I}=0.034 \mathrm{~g} / \mathrm{L} ; \\
\text { Milled }(3 \% \text { suspension, } 120 \mathrm{~min}): \\
V_{\max }=0.304 \mathrm{~g} / \mathrm{L} \cdot \min ; K_{m}=1.877 \mathrm{~g} / \mathrm{L} ; \\
K_{I}=0.016 \mathrm{~g} / \mathrm{L} ;\end{array}$ & {$[29]$} \\
\hline $\begin{array}{l}\text { Dilute sulfuric acid } \\
\text { pretreated coconut } \\
\text { coir }\end{array}$ & $r=\frac{V_{m} S_{0}}{K_{M}+S_{0}}$ & $\begin{array}{l}V_{m}=35.87 \mathrm{~g} / \mathrm{L} \cdot \mathrm{h} ; K_{M}=0.1306 \mathrm{~g} / \mathrm{L} ; \\
\mathrm{R}^{2}=0.9793 .\end{array}$ & {$[33]$} \\
\hline
\end{tabular}


termined from one batch experiment for each of unpretreated and pretreated coconut coir. The kinetic model by Cekmecelioglu and Uncu [30], gave very high maximum glucose concentration and first order kinetic constant as the kitchen waste also contain starch component which is more readily to degrade than cellulose. From the model of pretreated wheat straw [31], the maximum rate and glucose concentration is higher $(>10 \mathrm{~g} / \mathrm{L})$ because of high enzyme dose added (75 FPU/g glucan). The steam exploded rice straw [32] and dilute acid pretreated coconut coir [33] also reported higher maximum reaction rate but the maximum glucose concentration obtained is lower $(<1.2 \mathrm{~g} / \mathrm{L})$. The high solid loading waste papers [18] resulted in very high glucose concentration $(20->90 \mathrm{~g} / \mathrm{L})$ and from the high reported value of kinetic coefficients $\left(k_{2}\right.$ and $\left.k_{3}\right)$, it can be inferred that the hydrolysis rate is also high.

\section{Conclusions}

Mathematical model based on the Michaelis-Menten equation had been expanded involving stoichiometric relation between substrate concentration modeled as cellulose molecule and product concentration modeled as glucose molecule. This model is unique since it added one more constant representing the accessible initial substrate concentration $\left(S_{0}\right)$ constant to the Michaelis-Menten model in spite of the two basic coefficient $\left(r_{\max }\right)$, and constant $\left(K_{M}\right)$. The coefficient and constants of the expanded model had been determined from one batch experiment for each of the pretreatment method used. The model had shown the effect of pretreatment method using alkaline, ionic liquid, and both combination to the kinetic parameters of enzymatic hydrolysis. The best hydrolysis result was performed using combination of ionic liquid and $1 \%$ dilute sodium hydroxide solution with kinetic model parameter of $0.5524 \mathrm{~g} / \mathrm{L} . \mathrm{h}$ of $r_{\text {max }}, 0.0409 \mathrm{~g} / \mathrm{L}$ of $K_{M}$, and $4.1919 \mathrm{~g} / \mathrm{L}$ of $S_{0}$. The model can be extended and applied to the production of sugar not only from coconut coir, but also other lignocellulose waste by employing the combined pretreatment using alkaline and ionic liquid, prior to enzymatic hydrolysis.

\section{Acknowledgment}

The authors acknowledge funding from Ministry of Research and Technology of Republic of Indonesia (Ristek-BRIN) through Penelitian Hibah Doktor scheme. The first author also gratefully acknowledges the doctoral study funding from Indonesia Endowment Fund for
Education (LPDP), Ministry of Finance of Republic of Indonesia.

\section{References}

[1] Scarlat, N., Dalleman, J., Ferrario, F., Nita, V. (2015). The role of biomass and bioenergy in a future bioeconomy: Policies and facts. Environmental Development, 15, 3-34. DOI: 10.1016/j.envdev.2015.03.006.

[2] Shafiee, S., Topal, E. (2009). When will fossil fuel reserves be diminished?. Energy Policy, 37(1), 181-189. DOI: 10.1016/j.enpol.20 08.08.016.

[3] Pereira, L., Cavalett, O., Bonomi, A., Zhang, Y., Warner, E., Chum, H. (2019). Comparison of biofuel life-cycle GHG emissions assessment tools: The case $\mathrm{T}$ studies of ethanol produced from sugarcane, corn, and wheat. Renewable and Sustainable Energy Reviews, 110, 1-12. DOI: 10.1016/j.rser.2019.04.043.

[4] Chen, H., Fu, X. (2016). Industrial technologies for bioethanol production from lignocellulosic biomass. Renewable and Sustainable Energy Reviews, 57, 468-478. DOI: 10.1016/j.rser.2015.12.069.

[5] Aditiya, H., Mahlia, T., Chong, W., Nur, H., Sebayang, A. (2016). Second generation bioethanol production: A critical review. Renewable and Sustainable Energy Reviews, 66, 631-653. DOI: 10.1016/j.rser.2016.07.015.

[6] Chandel, A., Garlapati, V., Singh, A., Antunes, F., da Silva, S. (2018). The path forward for lignocellulose biorefineries: bottlenecks, solutions, and perspective on commercialization. Bioresource Technology, 264, 370381. DOI: 10.1016/j.biortech.2018.06.004.

[7] Menon, V., Rao, M. (2012). Trends in bioconversion of lignocellulose: Biofuels, platform chemicals \& biorefinery concept. Progress in Energy and Combustion Science, 38, 522-550. DOI: 10.1016/j.pecs.2012.02.002.

[8] FAOSTAT. (2017). FAOSTAT (Food and Agriculture Organization of the United State). Retrieved May 2019 , from http://www.fao.org/faostat/en/\#data/QC.

[9] Brandt, A., Gräsvik, J., Hallett, J., Welton, T. (2013). Deconstruction of lignocellulosic biomass with ionic liquids. Green Chemistry, 15, 550-583. DOI: 10.1039/c2gc36364j.

[10] Azarpira, A., Ralph, J., Lu, F. (2014). Catalytic Alkaline Oxidation of Lignin and its Model Compounds: a Pathway to Aromatic Biochemicals. BioEnergy Research, 7, 78-86. DOI 10.1007/s12155-013-9348-x.

[11] Coimbra, M., Duque, A., Saéz, F., Manzanares, P., Grazia-Cruz, C., Ballesteros, M. (2016). Sugar production from wheat straw 
biomass by alkaline extrusion and enzymatic hydrolysis. Renewable Energy, 86, 1060-1068. DOI: 10.1016/j.renene.2015.09.026.

[12] Lee, J. (2001). Biochemical Engineering. Washington, United States: Prentice-Hall, Inc.

[13] Alvira, P., Tomás-Pejó, E., Ballesteros, M., Negro, M. (2010). Pretreatment technologies for an efficient bioethanol production process based on enzymatic hydrolysis: A review. Bioresource Technology, 101, 4851-4861. DOI: 10.1016/j.biortech.2009.11.093.

[14] Chen, H., Liu, J., Chang, X., Chen, D., Xue, Y., Liu, P., Lin, H., Han, S. (2017). A review on the pretreatment of lignocellulose for highvalue chemicals. Fuel Processing Technology, $160, \quad 196-206 . \quad$ D O I : 10.1016/j.fuproc.2016.12.007.

[15] Sun, Y., Cheng, J. (2002). Hydrolysis of lignocellulosic materials for ethanol production: a review. Bioresource Technology, 83, 1-11. DOI: 10.1016/s0960-8524(01)00212-7.

[16] Taherzadeh, M., Karimi, K. (2008). Pretreatment of Lignocellulosic Wastes to Improve Ethanol and Biogas Production: A Review. International Journal of Molecular Sciences, 9, 1621-1651. DOI: 10.3390/ijms9091621.

[17] Kim, J., Lee, Y., Kim, T. (2016). A review on alkaline pretreatment technology for bioconversion of lignocellulosic biomass. Bioresource Technology, 199, 42-48. DOI: 10.1016/j.biortech.2015.08.085.

[18] Wang, Q., Wang, W., Tan, X., Zahoor, Chen, X., Guo, Y., Yu, Q., Yuan, Z., Zhuang, X. (2019). Low-temperature sodium hydroxide pretreatment for ethanol production from sugarcane bagasse without washing process. Bioresource Technology, 291, 121844. DOI: 10.1016/j.biortech.2019.121844.

[19] Nagarajan, S., Skillen, N., Irvine, J., Lawton, L., Robertson, P. (2017). Cellulose II as bioethanol feedstock and its advantages over native cellulose. Renewable and Sustainable Energy Reviews, 77, 182-192. DOI: 10.1016/j.rser.2017.03.118.

[20] Hayes, D. (2009). An examination of biorefining processes, catalysts and challenges. Catalysis Today, 145, 138-151. DOI: 10.1016/j.cattod.2008.04.017.

[21] Mohan, M., Deshavath, N., Banaerjee, T., Goud, V., Dasu, V. (2018). Ionic liquid and sulfuric acid-based pretreatment of bamboo: biomass delignification and enzymatic hydrolysis for the production of reducing sugars. Industrial \& Engineering Chemistry Research, 57 ( 31 ), $\quad 10105-10117$. D O I : 10.1021/acs.iecr.8b00914.
[22] Sangian, H., Kristian, J., Rahma, S., Agnesty, S., Gunawan, S., Widjaja, A. (2015). Comparative Study of the Preparation of Reducing Sugars Hydrolyzed from High-Lignin Lignocellulose Pretreated with Ionic Liquid, Alkaline Solution and Their Combination. Journal of Engineering and Technological Sciences, 47 ( 2 ), $\quad 137-148$. D O I : 10.5614/j.eng.technol.sci.2015.47.2.3.

[23] Sangian, H., Kristian, J., Rahma, S., Dewi, H., Puspasari, D., Agnesty, S.Y., Gunawan, S., Widjaja, A. (2015). Preparation of Reducing Sugar Hydrolyzed from High- Lignin Coconut Coir Dust Pretreated by the Recycled Ionic Liquid [mmim][dmp] and Combination with Alkaline. Bulletin of Chemical Reaction Engineering \& Catalysis, 10(1), 8-22. DOI: 10.9767/bcrec.10.1.7058.8-22.

[24] Miller, G. (1959). Use of Dinitrosalicylic Acid Reagent for Determination of Reducing Sugar. Analytical Chemistry, 31(3), 426-428. DOI: $10.1021 /$ ac60147a030.

[25] Dorman, J., Prince, P. A. (1980). Family of embedded Runge-Kutta formulae. Journal of Computational and Applied Mathematics, 6, 19-26. DOI: 10.1016/0771-050X(80)90013-3.

[26] Shampine, L., Reichelt, M. (1997). The Matlab Suite. SIAM Journal on Scientific Computing, 18, 1-22. DO I : 10.1137/S1064827594276424.

[27] Lagarias, J., Reeds, J., Wright, M., Wright, P. (1998). Convergence Properties of the Nelder-Mead Simplex Method in Low Dimensions. SIAM Journal on Optimization, 9, 112-147. DOI: 10.1137/S1052623496303470.

[28] Spiess, A., Neumeyer, N. (2010). An evaluation of R2 as an inadequate measure for nonlinear models in pharmacological and biochemical research: A Monte Carlo approach. BMC Pharmacology, 10(6), 4-11. DOI: 10.1186/1471-2210-10-6.

[29] Yeh, A., Huang, Y., Chen, S. (2010). Effect of particle size on the rate of enzymatic hydrolysis of cellulose. Carbohydrate Polymers, 79, 192-199. DOI: 10.1016/j.carbpol.2009.07.049.

[30] Cekmecelioglu, D., Uncu, O. (2013). Kinetic modeling of enzymatic hydrolysis of pretreated kitchen wastes for enhancing bioethanol production. Waste Management, 33, 735-739. DOI: 10.1016/j.wasman.2012.08.003.

[31] Monschein, M., Reisinger, C., Nidetzky, B. (2013). Enzymatic hydrolysis of microcrystalline cellulose and pretreated wheat straw: A detailed comparison using convenient kinetic analysis. Bioresource Technology, 128, 679687. DOI: 10.1016/j.biortech.2012.10.129. 
[32] Bin, Y., Hongzhang, C. (2010). Effect of the ash on enzymatic hydrolysis of steamexploded rice straw. Bioresource Technology, $101, \quad 9114-9119$. D O I : 10.1016/j.biortech.2010.07.033.

[33] Fatmawati, A., Agustriyanto, R. (2015). Kinetic study of enzymatic hydrolysis of acidpretreated coconut coir. AIP Conference Proceedings. $1699, \quad 030012$. DOI: 10.1063/1.4938297.
[34] Wang, L., Templer, R., Murphy, R. (2012). High-solids loading enzymatic hydrolysis of waste papers for biofuel production. Applied Energy, $99, \quad 23-31$. D O I : 10.1016/j.apenergy.2012.03.045.

Selected and Revised Papers from $3^{\text {rd }}$ International Conference on Chemistry, Chemical Process and Engineering 2020 (IC3PE 2020) (https://chemistry.uii.ac.id/ic3pe/) (Universitas Islam Indonesia (UII), Labuan Bajo, Nusa Tenggara Timur, Indonesia by $30^{\text {th }}$ September - 1st October 2020) after Peer-reviewed by Scientific Committee of IC3PE 2020 and Peer-Reviewers of Bulletin of Chemical Reaction Engineering \& Catalysis. Editors: Is Fatimah; I. Istadi 